\title{
Crissy Field \\ Methods
}

\section{Case Study Prepared by:}

Research Assistant: Chase Walz

Landscape Architecture Researcher/Intern

B.A. University of California Berkeley

Firm Liaison: Meghen Quinn

Principal, Hargreaves Associates

LAF Staff: Megan Barnes

Program Manager, Landscape Architecture Foundation

This case study was produced in 2019 as part of the Landscape Architecture Foundation's Landscape Performance Series. LAF staff worked with a student Research Assistant/Intern and firm representatives to document the project and its environmental, social, and economic benefits.

To cite:

Walz, Chase, Meghen Quinn, and Megan Barnes. "Crissy Field Methods." Landscape Performance Series. Landscape Architecture Foundation, 2019. https://doi.org/10.31353/cs1601

The full case study can be found at: https://landscapeperformance.org/case-study-briefs/crissyfield 


\section{$\underline{\text { Table of Contents }}$}

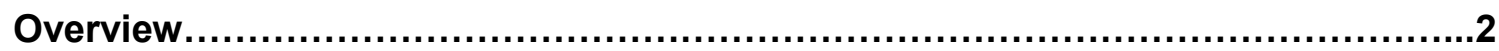

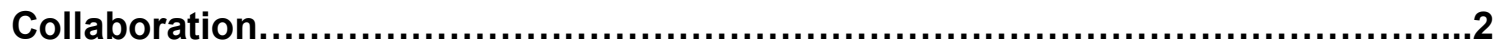

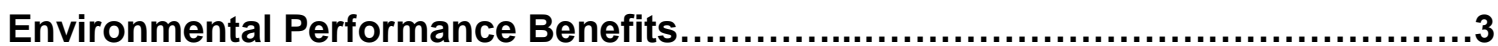

Social Performance Benefits...........................................................

Economic Performance Benefits...................................................15

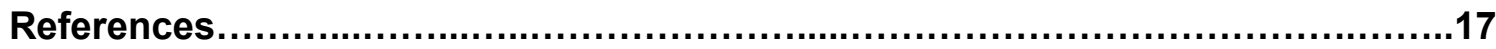

\section{Abbreviations}

CF Crissy Field

LAF Landscape Architecture Foundation

RLA Registered Landscape Architect

CSI Case Study Investigation 


\section{Overview}

100-acre Crissy Field represents the first of many large-scale projects to transform the U.S. Sixth Army's military installation at the Presidio in San Francisco, California into an urban national park within the Golden Gate National Recreation Area. Prior to European settlement, Crissy Field was part of an extensive backdune marsh used by the native Ohlone people that drained the Tennessee Hollow watershed into the San Francisco Bay. The marsh was filled in over many decades and became home to a U.S. Army military installation, and the site was decommissioned and transferred to the National Park Service in 1994.

The park's design re-established tidal marsh, restored vegetated dune fields, and rehabilitated the beach as a public amenity within a large city, creating a hybrid space in which both cultural and ecological systems thrive.

Crissy Field integrates diverse recreational uses within a dynamic ecological environment, all within the context of an enduring cultural landscape. Adaptive reuse of historic hangars and military buildings, combined with new educational facilities, transformed this formerly barren and restricted military-industrial area into a vibrant waterfront park.

\section{Collaboration}

This case study was successful due to the intense collaboration between the University of California, Berkeley, Hargreaves Jones, and the Landscape Architecture Foundation.

We wish to offer special thanks to the additional support we received throughout the process to the following individuals whom this extensive project could not have happened without:

From the National Park Service: Kristen Ward; Hargreaves Jones: Mary Margaret Jones, Senior Principal, Kirt Rieder, Principal, and the staff at the Crissy Field Center. 


\section{Landscape Performance Indicators}

\section{Environmental Performance Benefits}

1. Remediated approximately $38,000 \mathrm{cu}$ yds of contaminated soil on-site through low temperature thermal desorption, saving $\$ 7.6$ million in off-hauling costs.

Methods

Crissy Field's history left its soils compacted and contaminated. Documented impacts from military occupation included petroleum hydrocarbon plumes from aircraft fuels, pesticide plumes, and solvents from cleaning aircraft, military vehicles, and tanks.

To remediate the site before Crissy Field began construction, consultants Montgomery Watson and the IT Corp evaluated several strategies for contaminated soils. They ultimately selected low temperature thermal desorption (LTTD), a common practice at the time (the late 1990s), which entails the use of a large kiln to cook or heat the soil to $600-700^{\circ} \mathrm{F}$. According to Reider (2003) based on interviews with project consultants (Macluff 1998), approximately 38,000 cubic yards of contaminated soil was processed through the LTTD system.

\section{Limitations:}

Data was not independently verified by the CSI research team.

Historic data for the cost of the LTTD treatment was unavailable, which would have given a more accurate estimation of cost savings.

\section{Sources:}

Rieder, Kirt, ed. (2003). Manufactured Sites: Rethinking the Post-Industrial Landscape. 196198.

Hargreaves Jones, phone conversation, 10/30/2019.

2. Restored 40 acres of habitat consisting of 22 acres of vegetated dune and dune swale habitat and 18 acres of tidal marsh, allowing fresh and salt water to merge at Crissy Field for the first time in $\mathbf{1 0 0}$ years. 


\section{Methods:}

Information was sourced from Transforming Crissy Field by Brad Porter, P.E. Numerical measurements were gathered from the office of Moffatt \& Nichol, who completed the civil engineering for the site's restoration.

From 1998 through 2000, the restoration of this 100-acre site included the reestablishment of an 18-acre tidal marsh linked to the San Francisco Bay and the restoration of 22 acres of dune habitat in what was previously concrete and pavement. More than 230,000 cubic yards of dirt, sand, and mud were excavated and a channel was opened to the tides in November 1999, allowing freshwater (runoff from the Tennessee Hollow watershed) and salt water to merge at Crissy Field for the first time in 100 years.

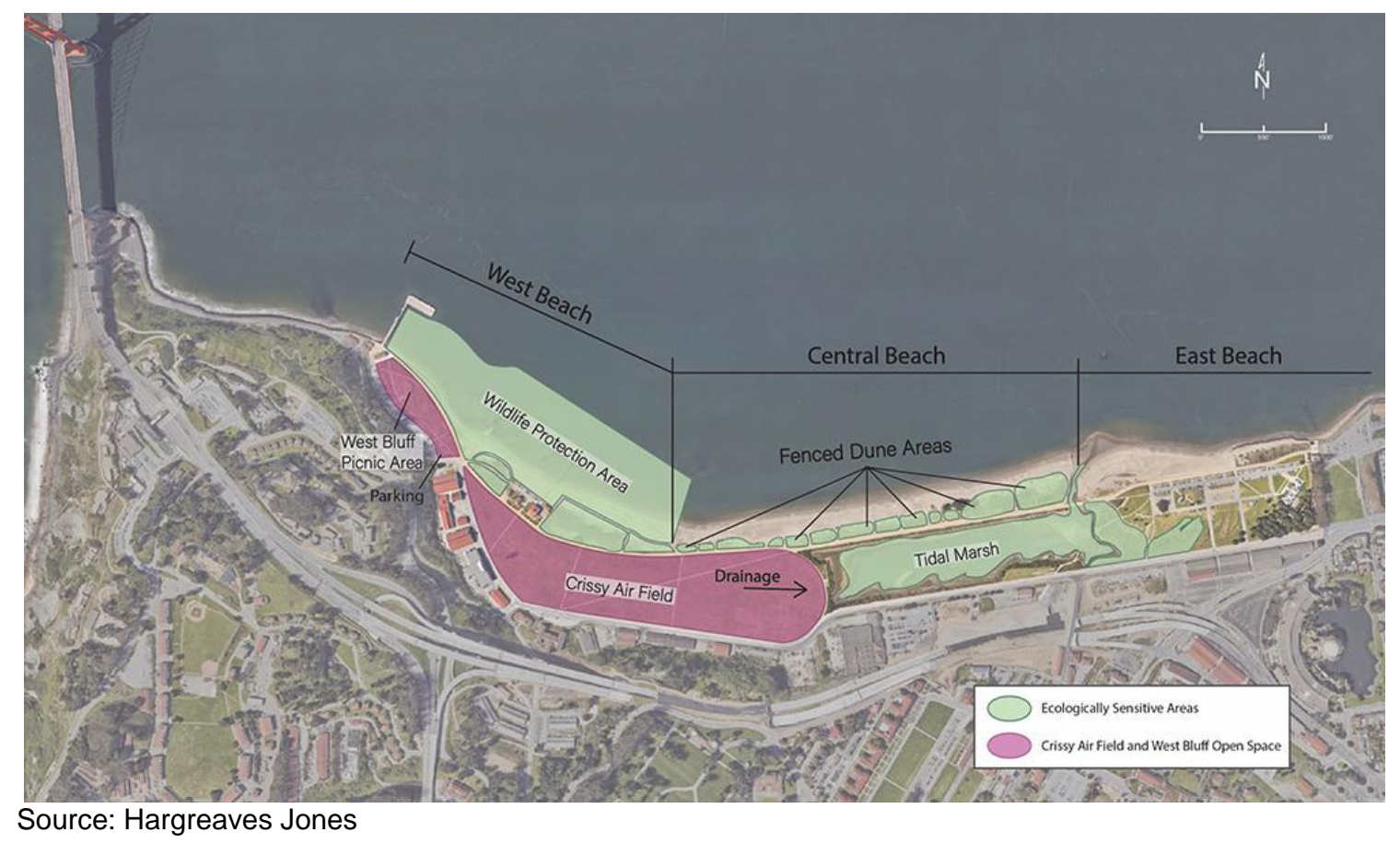

\section{Limitations:}

Measurements were taken in 2003 and have not since been independently verified by the CSI research team.

\section{Source:}

Porter, B. (2003). Transforming Crissy Field. Walnut Creek, CA: Moffatt \& Nichol Engineers. 


\section{Supports ongoing native species establishment, as evidenced by an increase in Native Species Richness from 4.2 to 5.2 in the high elevation marsh habitat between 2002 and 2004.}

\section{Methods:}

Information was sourced from the Crissy Field Restoration Project: Summary of Monitoring data 2000-2004, published by the National Park Service. According to the report, the vegetation monitoring was performed in the dunes and the marsh in all years from 2000 to 2004. The data reported was taken from 18 sets of three parallel transects which targeted high, middle, and low elevation bands within the intertidal zone. While all transects (low, middle, and high) showed an increase in native species richness, the highest transect showed the most notable increase and is therefore highlighted in this report.

Species richness along high marsh transects had a mean between 4.2 and 5.2 for species found along all transects between 2002 and 2004. The standard error was 0.6. 
Table 8 . Average percent (\%) cover and percent frequency of occurrence of algae and plant cover along 18 permanent transects at high elevations of Crissy Field Tidal Marsh, 2002-2004. (Species are listed in decreasing frequency of occurrence as measured in 2004.)

\begin{tabular}{|c|c|c|c|c|c|c|c|}
\hline $\begin{array}{l}\text { High Elevation Transects } \\
(\sim 6.5-7 \text { feet above MLLW) } \\
\text { Scientific Name }\end{array}$ & Common Name & \multicolumn{2}{|l|}{2002} & \multicolumn{2}{|l|}{2003} & \multicolumn{2}{|l|}{2004} \\
\hline & bare ground & 69 & 100 & 66 & 100 & 62 & 100 \\
\hline Distichlis spicata & salt grass & 10 & 78 & 13 & 83 & 18 & 89 \\
\hline Sarcornia pacifica & pickleweed & 3 & 67 & 2 & 83 & 4 & 83 \\
\hline-- & non-native forbs & 3 & 89 & $<1$ & 6 & 1 & 67 \\
\hline Spergularia macrotheca & beach sand spurry & 5 & 72 & 2 & 78 & 2 & 61 \\
\hline Spergularia marina(salina?) & salt marsh sand spurry & -- & -- & 2 & 44 & 1 & 56 \\
\hline Jaumea carnosa & salt marsh daisy & 1 & 22 & 3 & 44 & 2 & 50 \\
\hline Frankenia salina & alkali heath & 5 & 44 & 3 & 50 & 1 & 50 \\
\hline Plantago maritima & goose tongue & $<1$ & 33 & $<1$ & 11 & $<1$ & 50 \\
\hline Limonium californicum & sea lavender & 2 & 17 & $<1$ & 22 & $<1$ & 39 \\
\hline Ambrosia chamissonis & beach bur & $<1$ & 11 & -- & -- & 1 & 17 \\
\hline Atriplex triangularis & spearscale & 1 & 22 & $<1$ & 44 & $<1$ & 17 \\
\hline Grindelia stricta & marsh gumplant & 3 & 17 & $<1$ & 17 & $<1$ & 11 \\
\hline 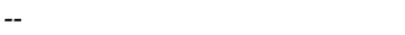 & non-native grasses & $<1$ & 17 & -- & -- & $<1$ & 17 \\
\hline Atriplex californica & Ca. saltbush & $<1$ & 6 & -- & -- & $<1$ & 11 \\
\hline Schoenoplectus pungens & & -- & -- & $<1$ & 6 & 5 & 6 \\
\hline Baccharis pilularis & coyote brush & -- & -- & -- & -- & $<1$ & 6 \\
\hline Armeria maritima ssp. californica & Ca. sea pink & -- & -- & -- & -- & $<1$ & 6 \\
\hline Triglochin concinna & arrow grass & $<1$ & 6 & $<1$ & 6 & $<1$ & 6 \\
\hline Juncus bufonius & toad rush & $<1$ & 17 & -- & -- & $<1$ & 6 \\
\hline Heliotropium curassavicum & salt heliotrope & $<1$ & 6 & -- & -- & $<1$ & 6 \\
\hline Festuca rubra & Red fescue & $<1$ & 6 & -- & -- & $<1$ & 6 \\
\hline Ulva and Enteromorpha sp. & algae & 3 & 50 & 3 & 83 & -- & -- \\
\hline Fragaria chiloensis & beach strawberry & $<1$ & 11 & $<1$ & 11 & -- & -- \\
\hline Atriplex leucophylla & beach saltbush & -- & -- & $<1$ & 6 & -- & -- \\
\hline Spartina foliosa & Pacific cordgrass & $<1$ & 6 & $<1$ & 6 & -- & -- \\
\hline Lupinus arboreus & yellow bush lupine & $<1$ & 6 & -- & -- & -- & -- \\
\hline Rumex occidentalis & & $<1$ & 6 & -- & -- & -- & -- \\
\hline Epilobium brachycarpum & willow herb & $<1$ & 6 & -- & -- & -- & -- \\
\hline \multicolumn{2}{|c|}{$\begin{array}{l}\text { Native Species Richness (Mean } \pm \text { S.E.) } \\
\text { Species Richness Range }\end{array}$} & \multicolumn{2}{|c|}{$\begin{array}{l}4.2 \pm 0.6 \\
0-9 \text { species } \\
\end{array}$} & \multicolumn{2}{|c|}{$\begin{array}{l}5.0 \pm 0.6 \\
0-9 \text { species } \\
\end{array}$} & \multicolumn{2}{|c|}{$\begin{array}{l}5.2 \pm 0.6 \\
1-9 \text { species } \\
\end{array}$} \\
\hline
\end{tabular}

Source: Crissy Field Restoration Project: Summary of Monitoring Data 2000-2004

\section{Limitations:}

The above data was not independently verified by the CSI research team.

Limitations to the data reported above also include:

Ongoing manipulation of the site continued through stewardship activities between 2000 and 2004, which may have affected the Species Richness. This included varying levels of weeding and additional outplanting. Second, monitoring methods did not remain consistent from 2002 to 2004 (see 2006 report). Efforts were made to analyze vegetation monitoring data and "marry" the different methods for interpretation. The 2006 report includes preliminary data from monitoring as well as general observations. 
Source:

Ward, K., \& Ablog, M. (2006). Crissy Field Restoration Project: Summary of Monitoring Data 2000-2004. National Park Service, 38-41.

\section{Provides habitat for $\mathbf{1 4 5}$ observed bird species representing $\mathbf{3 6}$ families, including 9 listed as endangered species or species of concern at a federal and/or state level, as observed from 2000 to 2004.}

\section{Methods}

Bird species incidence was evaluated for a 2006 report by the National Park Service on Crissy Field. 145 species from 36 families were detected in the restored habitats and along the beach and nearshore areas at Crissy Field in surveys conducted between June 2000 through July 2004 (Table 12). Of these, 98 species were observed in the wetland, 76 in the beach and nearshore areas, 64 in the foredunes, and 55 in the dune swale and rear dune area. An additional nine species have been observed either flying over the site, or in landscaped areas adjacent to the restored natural areas.

In all seasons and all years, the highest bird densities (\#birds/hectare) have been detected in the wetland, followed by the dune swale and rear dune. The lowest bird densities were detected in the foredunes and the beach and nearshore areas. Species richness (\# of species detected) was highest in the wetland, followed by the beach and nearshore areas, the foredunes, and the dune swale/rear dune areas. However, it should be noted that richness is presented by habitat and the size of the different search areas varies considerably. Bird species detected at Crissy Field include nine state- or federally-listed species. The brown pelican (Pelecanus occidentalis californicus, state and federally endangered) and the snowy egret (Egretta thula, federal species of concern) are both common visitors to Crissy Field. Additionally, the western snowy plover (Charadrius alexandrinus, federally threatened) has been observed roosting on the beach in the Wildlife Protection Area. Other listed species have been observed very infrequently or on just one occasion.

\section{Limitations:}

Due to project constraints, the data reported above was not independently verified by the CSI research team. 
According to the 2006 report, limitations were also reported as:

"The data did not appear to indicate a substantial difference in bird use by most species between high and low tides. However, detecting these differences may be confounded due to the muted tidal regime and temporally variable tidal range in Crissy marsh [during the monitoring period of 2000-2004]. To facilitate better comparisons between tides, staff gage readings are now recorded at the beginning of each survey. Although broad differences in use between tides were not detected, a couple of species did show different use patterns. Western and least sandpipers which forage in intertidal areas, were nearly twice as abundant during low tides than during high tides in both 2002 and 2003." (Ward 2006).

\section{Source:}

Ward, K., \& Ablog, M. (2006). Crissy Field Restoration Project: Summary of Monitoring Data 2000-2004. National Park Service, 54-57.

\section{Provides habitat for at least 19 species of fish representing $\mathbf{1 2}$ families and at least 13 macrocrustacean species as observed in Crissy Marsh from 2000 to 2004.}

\section{Methods}

According to Ward and Abalog's 2006 report, fish and epibenthic macrocrustaceans were sampled quarterly (January, April, July, October) at five locations around the tidal marsh: four intertidal sites along the wetland shoreline (stations F1, F2, F3, F5), one subtidal site (station F4) and one site in the inlet channel (station F6). Each of the intertidal stations encompassed a shoreline length of $100 \mathrm{~m}$. Three seining locations were randomly selected along this distance.

Of the fish sampled, the "numerically dominant species were Clevelandia ios (arrow goby), Atherinops affinis (topsmelt), Gasterosteus aculeatus (threespine stickleback), Ilypnus gilberti (cheekspot goby), and Leptocottus armatus (Pacific staghorn sculpin). Two non-native fish species were collected in Crissy marsh between 2001 and 2004: Acanthogobius flavimanus (yellowfin goby), and Luciana parva (Rainwater killifish). Although relatively high numbers of yellowfin gobies were caught in summer 2000, summer 2001, and spring 2002 (50, 404 and 183 fish, respectively), none were observed between summer 2003 and 2004 (2 fish). Rainwater killifish were observed once in winter 2001 ( 2 fish) and again in 2003 (3 fish). Approximately $90 \%$ of the fish taxa collected at Crissy Field during this time period were native. In comparison, approximately $85 \%$ of the fish taxa collected in California Department of Fish and Game 
(CDFG) midwater trawl surveys conducted in San Francisco Bay between 1980 and 2001 were native species (The Bay Institute, 2003)." (Ward 2006).

The benthic macroinvertebrate community was sampled following Environmental Monitoring and Assessment Program (EMAP) protocols for collection, processing, reporting, and quality control (U.S. EPA 1995, 2001a, 2001b). It should be noted that the habitat created by the restoration previously consisted of brownfield and greyfield land with none or very limited aquatic life.

The most abundant macrocrustacea species caught in seines at CF is Hemigrapsus oregonensis (yellow shorecrab) followed by Crangon nigricauda (Blacktail bay shrimp). The next three most commonly detected species were Crangon franciscorum (California bay shrimp), Heptacarpus brevirostris (stout coastal shrimp) and Heptacarpus paludicola (California coastal shrimp). Crangon shrimp are prey for many estuarine fishes. Two non-native taxa have been collected: Palaeamon macrodactylus and Carcinus maenas (European green crab). Forty individuals of the European green crab were caught in summer 2003 and two individuals were caught in summer, 2004.

Sampling Locations:

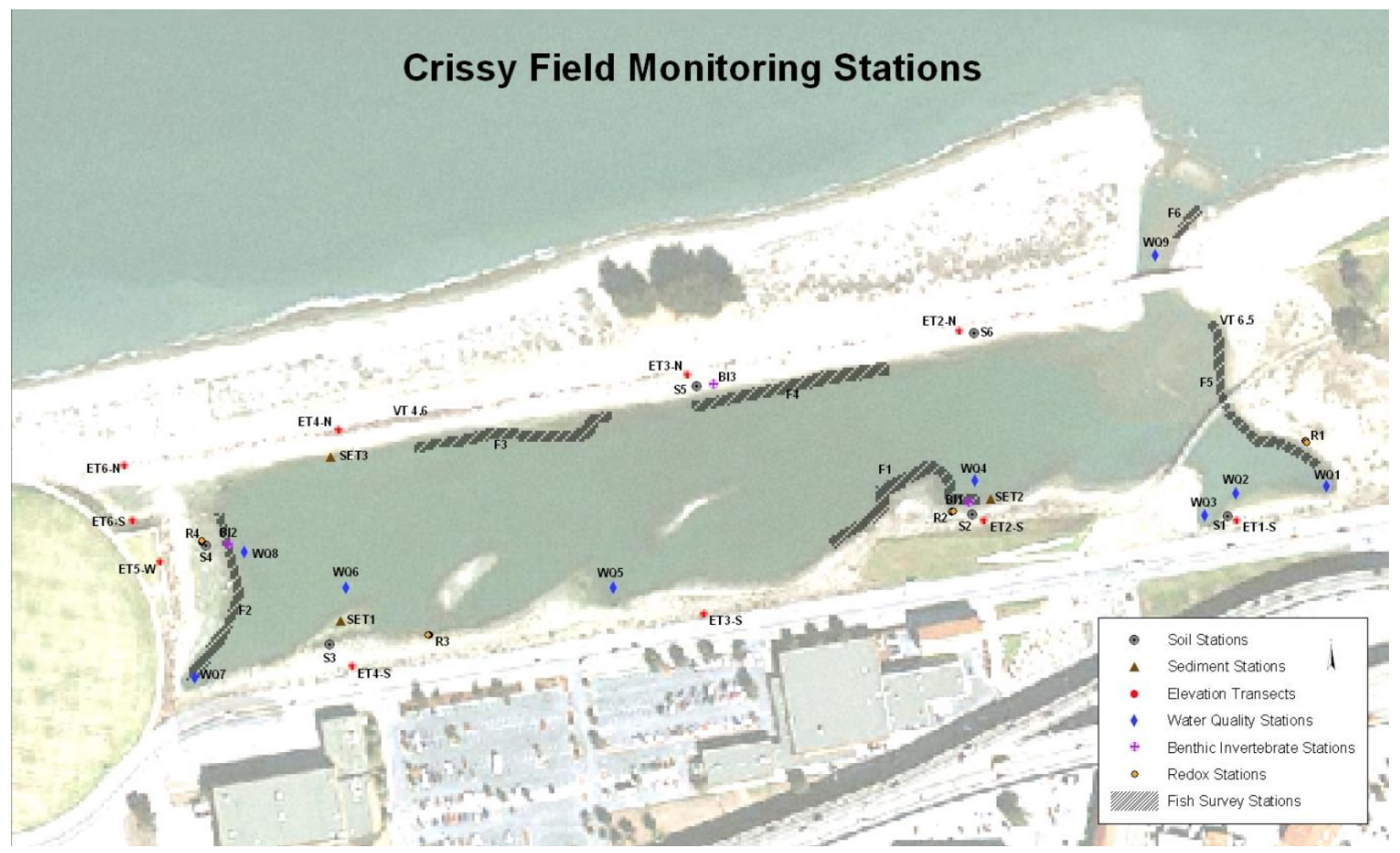

Source: Crissy Field Restoration Project: Summary of Monitoring Data 2000-2004 


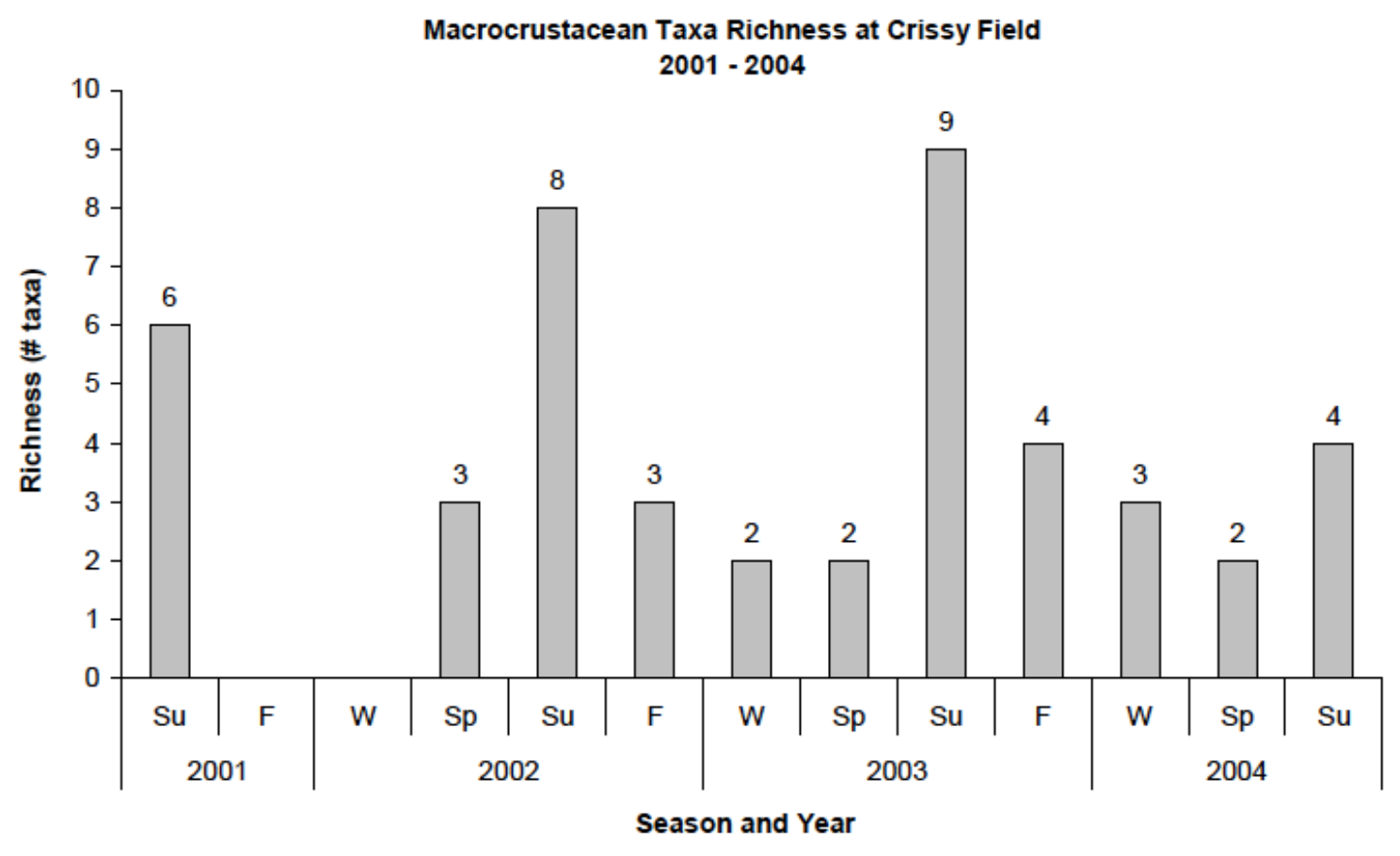

Source: Crissy Field Restoration Project: Summary of Monitoring Data 2000-2004

\section{Limitations}

Data was not independently verified by the CSI research team.

In addition to the larger crab and shrimp taxa, amphipods and mysid shrimp are often abundant in CF fish seines. However, these taxa are not identified or counted during NPS surveys. Also, macrocrustacean densities and richness are highest in the summer months. Taxa richness has ranged from 2-9, with the most taxa generally found during summer sampling events (5-9) and the lowest in fall and winter (2-3 taxa).

\section{Source}

Ward, K., \& Ablog, M. (2006). Crissy Field Restoration Project: Summary of Monitoring Data 2000-2004. National Park Service, 22-23 and 54-57. 


\section{Social Performance Benefits}

1. Attracts $\mathbf{1 . 2}$ million annual visitors including hikers, bikers, board-sailors, paragliders, dogwalkers, and families from around the Bay Area and across the globe.

\section{Methods}

Visitor numbers were gathered from published National Parks Service attendance data. Quantity is an estimate resulting from a combination of methods including traffic counters, manual counting on site by employees, and Crissy Field Center check-in data.

\section{Limitations}

Data was not independently verified by the CSI research team. Limited information was shared by the publisher of the 2016 report regarding the methods by which this information was obtained.

\section{Sources}

Brulliard, N. (2016, March 2). Who Counts? A Closer Look at Parks' Record Visitation Numbers.

Hsu, Michael. 2016 Report to the Community. Publication. Golden Gate National Parks Conservancy. parksconservancy.org, 2016. 5-6.

2. Provided environmental education for 693,000 children, youth, and community members in 2016 alone through programs at the Crissy Field Center including young leaders programming, school and community group programming, and educator trainings. Children from 70 different schools representing 8 school districts across the area participated in programs in 2018.

\section{Methods}

Data extracted from NPS data review of programs and visitorship. Environmental education programs focus on the park's ecology, sustainability, and biodiversity. Each participant received an average of 15.8 hours of contact time within the programs.

Located past the entrance of the Crissy Field park, the Crissy Field Center is a youth leadership and education facility serving young people, their families, and youth-serving adults. 
Attendance and engagement data for 2018 school districts gathered by the Crissy Field Center. According to the 2018 Crissy Field Center Report, the center implements a "ladder of learning" approach and multiple, stepped programs promote long term relationships in order to provide assistance to youth both personally and professionally. Intentional youth development and multicultural education practices are applied to teach leadership skills and to provide career choice opportunities with national parklands becoming avenues for practicing new skills and careers. The majority of the programs are provided for free or at very low cost in multiple languages.

\section{Limitations}

Data was not independently verified by the CSI research team. The report mentioned that "most" of the Crissy Field Center programming is free or very low cost but no information was provided on cost specifics.

Sources

Hsu, Michael. 2016 Report to the Community. Publication. Golden Gate National Parks Conservancy. parksconservancy.org, 2016. 5-6.

Crissy Field Center 2018 Annual Report. Publication. Golden Gate National Parks Conservancy. parksconservancy.org, 2018. 1-2.

\section{Economic Performance Benefits}

1. Catalyzes funding for ongoing maintenance; for example, a $\$ 2.5$ million donation and matching grant was secured in $\mathbf{2 0 1 6}$ for resurfacing the Crissy Field promenade and enhancing amenities.

\section{Methods}

The National Park Service Centennial Challenge is a 10-year effort to fund deferred maintenance on national parks for their continued conservation, preservation, and public enjoyment. Centennial Challenge signature projects provide no less than fifty percent matching for upgrades to parks (50 percent of the total cost of each project or program is derived from non-Federal sources). The proposal for Crissy Field's promenade resurfacing was created in coordination with NPS managers which was then submitted through the NPS Project 
Management Information System (PMIS) for priority setting by a panel who recommended to Regional Directors and the NPS Director projects for approval in accordance with Centennial Challenge priorities. The approved projects are placed on an eligible list to receive funding, when available. Crissy Field was awarded one of these grants for $\$ 2.5$ million, which was matched by donations from the Haas, Jr. Fund and members of the Golden Gate National Parks Conservancy.

\section{Limitations}

Data was not independently verified by the CSI research team.

\section{Sources}

Hsu, Michael. 2016 Report to the Community. Publication. Golden Gate National Parks Conservancy. parksconservancy.org, 2016. 5-6.

National Park Service Centennial Challenge. (2016). Retrieved from https://parkplanning.nps.gov/projectHome.cfm?projectID=63094. 


\section{References and Selected Publications:}

Brulliard, N. (2016, March 2). Who Counts? A Closer Look at Parks' Record Visitation Numbers.

Crissy Field. (2019, May 2). Retrieved from https://www.haasjr.org/issuesimpact/community/crissy-field.

Crissy Field Center 2018 Annual Report. 2018). Publication. Golden Gate National Parks Conservancy. parksconservancy.org. 1-2.

Edited by Fryberger, Betsy. (2003). The Changing Garden: Four Centuries of European and American Art. Berkeley, Los Angeles, London: University of California Press.

Ellis, John. (2002). View from San Francisco. The Architectural Review, January.

Heimbinder, Erin. (2001). Revegetation of a San Francisco Coastal Salt Marsh, Spring. Native Plants Journal, 54-59.

Porter, B. (2003). Transforming Crissy Field. Walnut Creek, CA: Moffatt \& Nichol Engineers.

Hsu, Michael. (2016). Report to the Community. Publication. Golden Gate National Parks Conservancy. parksconservancy.org, 2016. 5-6.

Markings. (2003). Landscape \& Art: The Journal of the Landscape \& Arts Network. Number 29. (Summer).

Melcher, Katherine. 2003. Field of Vision. Landscape Architecture Magazine, August.

National Park Service Centennial Challenge. (n.d.). Retrieved from https://www.federalgrantswire.com/national-park-service-centennialchallenge.html\#.XbCbz5NKjBI.

Ward, K., \& Ablog, M. (2006). Crissy Field Restoration Project: Summary of Monitoring Data 2000-2004. National Park Service, 38-41. 